\title{
Economic Feasibility Study for Petroleum \\ Projects \\ (Practical Aspects)
}

\author{
Dr. Hisham Yas Shaallan \\ Economical Directorate, Ministry Of Oil
}

\section{Abstract:}

An increasing importance is given to the Economic Feasibility Study of Petroleum Projects. The reason behind that is the critical role played by the Petroleum Industry in Society, Economy and Foreign Trade. In general, Petroleum Industry is involved with the Exploitation of Oil and Gas Resources to satisfy the country's needs (households and industrial sectors) and to export these resources, in order to, gain foreign currencies which are necessary for

funding the country's social and economic requirements. Petroleum Projects have diversity features in terms of location, size, capital, technology and risks. On the Other hand, because of the importance of the Petroleum Industry, high significance should be given to the Economic Feasibility Study, especially the necessary of good knowledge of the nature of Petroleum Activities, Projects and Contracts, as well as the fundamentals of Advanced Feasibility Study. 


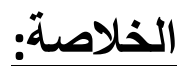

تزداد أهمية موضوع دراسة الجدوى

الاقتصادية للمشرو عات البترولية لأسباب عديدة

في مقدمتها أهمية الصناعة البترولية للاقتصاد

والمجتمع والعلاقات التجارية الدولية. الصناعة

البترولية، عموماً، تختص باستغلال الموارد

الهيدروكاربونية وسد حاجة البلد من المنتجات

النفية و الغازية سواء للقطاع الأسري أو

الصناعي أو في التجارة الخارجية لكسب عملات

صعبة تكون ضرورية لتمويل متطلبات التنمية

الاقتصادية والاجتماعية للبلد. مشروعات

الصناعة البترولية لها خصائص متنوعة من

حيث الموقع والحجم ورأس المال والتكنولوجيا

و المخاطر. وفي الجانب الأخر ، وبسبب طبيعة

الصناعة البترولية وأهميتها، يكتسب موضوع

دراسة الجدوى الاقتصادية في المشروعات

البترولية أهمية خاصة لاسيما مايتعلق منها

بضرورة المعرفة الجيدة بطبيعة الأنشطة

و المشروعات و التعاقدات الجديدة و أساسيات

در اسات الجدوى ومضامينها و التقدم المتحقق في

أساليب الدر اسة الحديثة وتقنياتها ـ

\section{Introduction:}

The subject of an Economic

Feasibility Study for Petroleum

Projects has recently gained increasing importance. Petroleum projects specialize in the exploitation of oil and gas resources and their products which are used in most of our daily needs. These projects have specific features related to the nature of their activities, location, capital, technology, risks and uncertainty. Therefore, those features require specific considerations pertinent to practical experience whether the study for upstream or downstream projects. Advanced knowledge about the fundamentals and techniques of a modern economic feasibility study, as well as specific knowledge about the requirements of establishing and operating petroleum projects and their developments, all are necessary issues to conduct a systematic study that enables involved parties to make reasonable decisions about available investment opportunities in petroleum industry.

Focusing on the requirements and the implementation of a modern economic feasibility study for petroleum projects is the main purpose of this paper through six parts. 


\section{Part One}

\section{Economic Feasibility Study:}

\section{1: Definition}

In general, an Economic

Feasibility Study as a tool is a series of interrelated and subsequent studies, used by companies, banks, investors, promoters, individuals and government agencies, that to consider a new project as an investment opportunity among many opportunities by studying their future cost and future revenue to find out and adopt the best options. This tool involves different uses of data and information related to marketing, technical, economic, financial, environmental, social and legal areas (monetary, quantitive and qualitative expressions) to build specific projections about the establishment and operation of the project. The initial investment and operating costs are expressed in monetary terms. A monetary expression is necessary to calculate the expected revenues, net cash flows, and net benefits or profitability indicators, taking into account the time value of money, risk factors and changing conditions, to make an initial judgment on a project proposal.

\section{2: Methodology:}

$\mathrm{An}$ Economic feasibility study is a set of diversified processes, starting from a simple idea heading toward several directions, then ending to form a complex study or simple report (project proposal) at hand for decision-makers. The ideas are designed to produce new goods or services, (or modify, modernize or renew given goods and services, etc). Basically, these ideas require an examination of their market features. A market study includes all the available data and information about the markets of inputs and outputs and their components; location, site, size, specifications, linkages, rules and laws, projections, etc. If positive results have been obtained (from a market viewpoint) this will open a way to continue for studying the technical framework options of the project. 
In principle, technical analysis is an essential step, maybe it is the Most important step. This analysis go deeply to study the project elements that are related to project shape, size, design, specifications, technology level, buildings, inputs, outputs, equipments, labor and services,...etc. All these elements are organized in the form of technical, monetary, and time schedules. Integrated technical analyses are often classified into investment costs and operating costs, which shall determine whether or not the project analysis needs to terminate, to modify or to continue to the next step. That is, the encouraging results will be the base for the financial analysis.

Many factors are required to achieve an accurate financial analysis because the final judgments will ultimately depend on the future financial results of project. Financial analysis deals with the commercial viability over the lifetime of a project. Many issues should be covered in this step, including various factors that are firstly required during the investment phase; (e.g. funding sources, financing terms, and the amount of loans and interests), as well as all the issues related to future costs and revenues. Profitability indicators to evaluate and judge the project viability may be simple such as; (Net Profit, Average Profit, and Payback Period). Indicators may be complex as well, such as; (Internal Rate of Return, Net Present Value, Discounted Payback Period and Profitability Index.), Indicators may also be more extended to comprise diverse financial statements of the project such as statements of; (Net Income, Cash Flow, and Budget) with selected financial Ratios. These basic items are shown in Table (1). 
Table (1)

Basic Indicators of a Financial Evaluation

\begin{tabular}{|c|c|}
\hline Undiscounted and Discounted Methods & Rate of Return \\
\hline & Payback Period \\
\hline & Net Present Value NPV \\
\hline & Internal Rate of Return IRR \\
\hline & Break-Even Point \\
\hline & Capital Productivity Index \\
\hline & Profitability Index \\
\hline & NPV/MAX Exposure Point \\
\hline & Others \\
\hline Financial Statements & Balance Sheet \\
\hline & Income Statement \\
\hline & Cash Flow Statement \\
\hline Financial Ratios & Current Ratio \\
\hline & Profit Margin \\
\hline & Return on Equity \\
\hline & Return on Assets \\
\hline & Interest Coverage \\
\hline & Debt to Equity \\
\hline & Debt to Total Capitalization \\
\hline & Others \\
\hline
\end{tabular}

The economic and financial results of the project will determine, to a great extent, the importance of the project for decision makers. They will decide whether the project is a good investment opportunity or not, or if there is a need to make modifications about the basic assumptions and/or initial calculations related to issues such as project design, production profile, technology level, investment expenditures, operating costs, products prices, etc. 
As a completed methodology, big projects require extensive analysis which should extend to cover environmental topics and a social profitability analysis. But in small projects these analyses are often neglected.

In short words, a feasibility study of a project comprises a market analysis, a technical analysis, and a financial analysis. The findings are the resulting study which is referred to as an (Economic Feasibility Study).

\section{3- Practical Requirements:}

In practice, there are varied requirements for the feasibility study process; First: a special team should be formed to undertake this task. The team mainly consists of specialists such as; (an experienced manager, engineers, economist, accountant, legal expert and a coordinator). Second: providing a technical background expressed as technical data and information of the project which is an essential source for computing the capital expenditures and operating costs. Third: legal frameworks and regulations that should be up to date, involving taxes, duties and any other financial obligations the project will be subjected to.

Fourth: gathering economic data about supply and demand, market prices, inflation rate, interest rate, etc. Fifth: use software programs which have been designed for economic and financial evaluation purposes. All of those requirements should be combined and integrated throughout the economic feasibility study.

\section{Part Two}

\section{Petroleum Industrv:}

\section{1: Definition}

\section{The Petroleum Industry is one}

of the most important industries in the world. This industry has special characteristics and requirements; a huge capital, advanced technology, senior specialists, high risks, specific skills and experience, long term projects and high sensitivity to political and economic events.

Generally, the petroleum industry has diverse activities related to the 
exploitation of oil and gas resources

under and above the ground, starting

from the pre-exploration efforts,

exploration, development and

production, transportation, refining,

gas processing, local distribution and

external marketing (see fig 1 ).

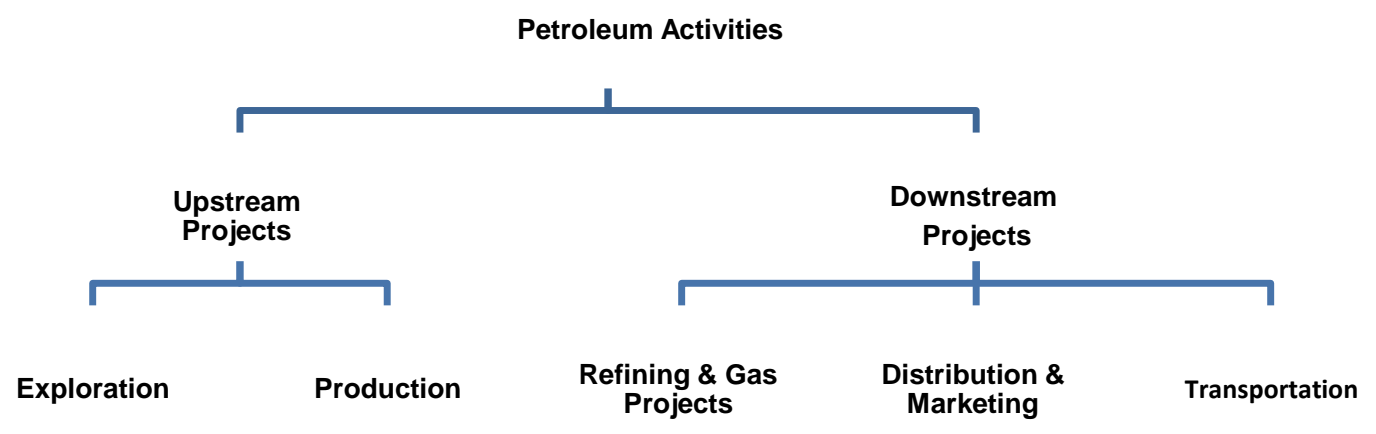

Fig. (1)

The Main Activities of the Petroleum Industry 
In spite of the specific features, especially the issues that pertain to capital requirements and the number of employees, type of inputs and outputs, location, and level of risks, .etc, most of these issues are interrelated and integrated.

\section{2: Petroleum Projects:}

A petroleum project as an investment opportunity may not considerably differ from projects in other industries. Simply, it is an allocation of a certain amount of capital to be spent on specific production factors which are required to establish a new project with commercial objectives in one or more activities .

As an integrated part, it is necessary to distinguish between the types of petroleum project evaluations; whether simple or complex, high cost or low cost, high risk or low risk, are for a company, investor, or government, all these factors will determine the directions and the implementation of an economic feasibility study.

Petroleum Projects involve various activities regarding inputs and outputs, markets, cash flows, locations and sites, etc. In this context, for any petroleum project, funds which are spent during the initial investment at an earlier period will be channeled into hundreds of directions; for instance, purchase equipments and materials from various sources, recruitment of expertise, contracting with a number of companies to undertake some designs or conduct certain works and services, etc. In contrast, expected revenues may be received after a relatively long time span, under uncertain conditions, and only from selling one or a few products.

Table (2) describes the main items of investment and operating costs and cash flows of the petroleum projects which consists of the categories of the basic cash flow for each type of petroleum projects. 
Table (2)

Petroleum Projects: Main Items of Cash Flow

\begin{tabular}{|c|}
\hline Exploration \& Production Project \\
\hline $\begin{aligned} \text { - Cash Inflows } \\
-\quad \text { Revenue from selling produced volumes of oil and gas in } \\
\text { Royalty/Tax fiscal systems } \\
-\quad \text { Cost Recovery and Profit Share in Production Sharing } \\
\text { Contracts } \\
\text { - Cash Outflows } \\
-\quad \text { Capital Expenditures to explore and develop the field } \\
-\quad \text { Operating Costs to maintain equipment and transport } \\
\text { production to market } \\
\text { Royalties, taxes and any other payments to government } \\
\text { entities as defined by special Hydrocarbon Laws, } \\
\text { negotiated contracts and tax legislation }\end{aligned}$ \\
\hline Gas Processing Plants \\
\hline 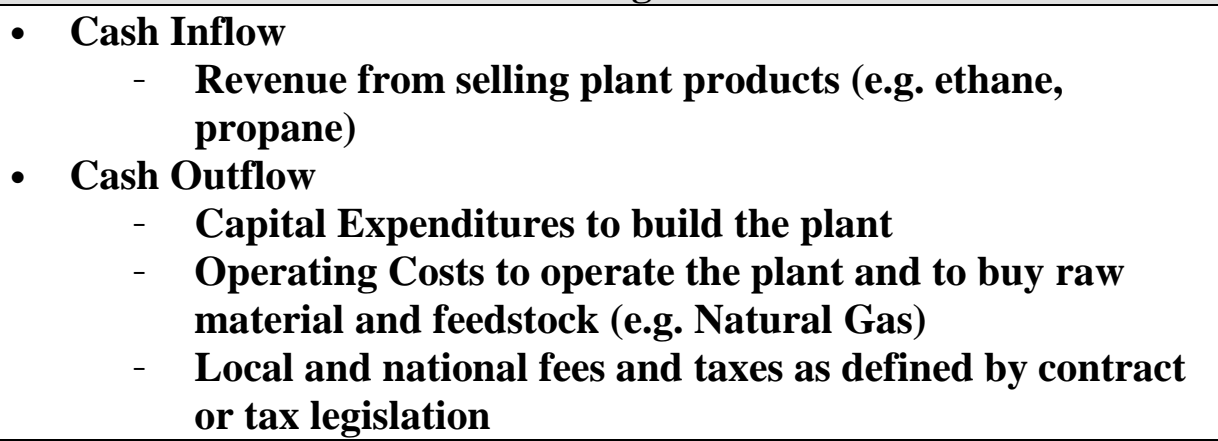 \\
\hline Refining Projects \\
\hline $\begin{array}{l}\text { - Cash Inflow } \\
-\quad \text { Revenue from selling refining products (e.g. Benzene, } \\
\text { Gas oil) } \\
\begin{aligned} \text { - Cash Outflow } \\
-\quad \text { Capital Expenditures to build the Refinery } \\
-\quad \text { Operating Costs to operate the Refinery and to buy } \\
\quad \text { feedstock (Crude oil)... } \\
-\quad \text { Local and national fees and taxes as defined by contract } \\
\text { or tax legislation }\end{aligned}\end{array}$ \\
\hline Pipeline Projects \\
\hline $\begin{array}{l}\text { - Cash Inflow } \\
-\quad \text { Revenue from tariffs charged to those transporting } \\
\text { products in the pipeline } \\
\text { - Cash Outflow } \\
-\quad \text { Capital Expenditures to build the pipeline } \\
-\quad \text { Operating Costs to maintain the pipeline and its } \\
\text { - } \text { equipment } \\
\text { Local and national fees and taxes as defined by contract } \\
\text { or tax legislation }\end{array}$ \\
\hline
\end{tabular}

Source: IHS ENERGY, 2005. 


\section{Part Three}

\section{Risks and Uncertainty Analysis:}

In a business life cycle, nothing

is $100 \%$ in future events. An economic feasibility study, as a comprehensive picture of a proposed project, should involve future cash in and future cash out and must be coupled with reasonable assumptions. The reasons beyond that are many known and unknown affected factors over the life of project and the frame that deals with these factors called (risks and uncertainty analysis).

Petroleum projects are quite sensitive to changing circumstances, especially those related to the inside development of projects (markets, costs and revenues), as well as events related to inflation, exchange rates, etc. All Those have a significant effects on the total value of project. Therefore, the risks and uncertainty analysis forms a key part in any economic feasibility study of petroleum projects.

\section{1: Definition:}

Generally, risks and uncertainty have no specific definitions; also they are diferent from other industries and activities. Risks and uncertainty cover all the unusual and unknown, expected and unexpected conditions which affect over the life of project, whether that is attributed to technical factors, environmental factors, political and social factors, or financial and economic factors. The direct results of these factors, if they are considered in an economic feasibility study, will generate more than one expected value for the project. This case is a critical point for decision makers who aim to determine a specific value or at least very close values.

The knowledge and practice of past and current events, and the ability to project certain future conditions that could cause a large loss, or even affect achieving the objectives of a project is called (Risk Analysis). But the absence or a little practice about past conditions and the inability to project some affected conditions and 
their type, is called (Uncertainty Analysis). In realty, there is no quite Separation between risks and uncertainly

\section{2:Techniques:}

In order to study the impact of potential factors (Risks and Uncertainty Analysis) the factors should be treated and determined at quantity levels, then in monetary expression. This step is so necessary in an economic feasibility study that deals and aims to reach the specific monetary values of a project. Entering risks and uncertainty analysis into the calculations of a feasibility study, a number of results will be produced. This means there is more than one value of a project to be achieved, up and down the level of base value.

Different techniques are used with this analysis, ranging from simple methods to the complex, but the nature of project and the details that are required will determine which techniques should be used. For instance, some commonly used techniques (with simple and complex projects) are as follows:

1. Sensitivity Analysis

2. Probability Analysis

3. Monte Carlo Simulation

4. Methods of High Discount Rate, Maximizing Payback

Period

\section{3: Risks and Uncertainty in}

\section{Petroleum Industrv:}

Concerning the petroleum industry, for example in case of Upstream Projects, in addition to economic and financial risks, there are numerous geological risks. Decisions to drill almost invariably have to be made on the basis of insufficient information. There are uncertainties about the porosity and permeability of reservoir rocks, hydrocarbon reserves in the reservoir, etc. Also, there are technical and non-technical risks associated with the successful drilling and completion of the wells, etc. (Krishan A. Malik).

On the other hand, Downstream projects may face different unusual 
events; many changing circumstances are associated with production operations such as crude oil prices, product prices, maintenance costs, sudden shutdowns, marketing problems....and so on. Gas plants also face circumstances that may be expected but some are not, for example feed gas price, long term contracts, or geo-political events.

Treatment of these events is different from case to case, depending on the nature of the project and the goals of feasibility team.

\section{Part Four}

\section{Software Programs:}

In practice, an economic feasibility study of a petroleum project is a complex process and includes Intensive efforts, whether that is linked to collect and organize data, or this data is treated to obtain accurate results. The process contains many factors and relations, and requires notably understanding not only what is related to the nature of project, but also all the steps and the phases of the path of the feasibility study. Using the advanced technology of the computer had created a number of software programs which are used in broad areas and have the ability to perform many tasks especially for the petroleum project evaluations.

\section{1: Definition:}

Software programs are a set of systems, based on mathematical and statistical logic that have been developed by specialists to achieve a variety of tasks related to all areas of sciences. The most important advantages of these programs are their capabilities to store, organize and analyze huge data and information, in an easy and quick way. Additionally, these programs draw the (Project) in a very detailed picture, covering all data as inputs and all results as outputs, involving tables, diagrams and figures, as well as different systems of equations and formulas. 


\section{2: Types of Petroleum Programs:}

$P_{\text {ractically, the analysis of various }}$ activities requires different software programs, and then a variety of structures and applications. Today, there are many types of software programs, depending on their purposes. Simple programs are often used for small projects, but complex and expensive ones are used for large projects. Simple programs are often free and they include a limited number of factors regarding some technical information and fundamentals of cash flows as well as main evaluation indicators. Complex programs extend to the more details to cover as much technical, financial, and economic data as possible. For petroleum projects, complex programs are commonly used in areas of (Upstream Projects) and (Downstream Projects). The design and the components of software programs involve many fields in addition to financial, economic, and accounting concepts, many details related to technical analysis are included and many techniques cover risks and uncertainty analysis.

Since there are many petroleum activities, a number of software programs such as exploration, development and production programs, and some other programs concerning refining projects and pipeline programs have been produced and developed to meet many purposes within an economic feasibility study.

The work with software programs requires, first of all, a wide awareness and good experience concerning the nature of the proposal project, specific skills for using computers, good knowledge of an economic evaluation, and some principles about mathematical and statistical tools. Because the complex software programs are very expensive and are often restricted in use with limited time, using these programs needs a high degree of efficiency to perform these tasks. 


\section{Part Five}

\section{Petroleum Contracts:}

$\mathrm{H}_{\text {igh attention is given to oil and }}$

gas resources because their inputs

are valuable and interrelated with

most of our life needs. Petroleum contracts are the basic tools of oil and gas exploitation in the world, which cover the activities of exploration, development and production. Exploitation efforts of oil and gas resources require huge capital, advanced technology and high experience; therefore, only experienced companies can have those capabilities to be involved. The essential point in this context is that petroleum contracts are concluded between Host Governments and Oil Companies. Each party has a different philosophy and objectives as shown in Table 3.

Table (3)

Objectives of Host Government and Oil Company

\begin{tabular}{|c|c|}
\hline Parties & Main Objectives \\
\hline Government & $\begin{array}{l}\text { - Maintaining control over resources } \\
\text { - Attracting risk investments } \\
\text { - Meeting domestic consumption requirements } \\
\text { - Maximizing national revenues from petroleum } \\
\text { - Developing indigenous technology and expertise } \\
\text { - Promoting national economic growth through petroleum } \\
\text { development by foreign companies. }\end{array}$ \\
\hline Company & $\begin{array}{l}\text { - Seeking Oil \& Gas discoveries } \\
\text { - Obtaining a reasonable rate of return } \\
\text { - Securing crude oil supply } \\
\text { - Ensuring sufficient security on investment } \\
\text { - Retaining as much flexibility and control of the operation } \\
\text { as possible. }\end{array}$ \\
\hline
\end{tabular}




\section{1: Definition:}

$S_{\text {imply, the petroleum contract }}$ consists of specific arrangements, mainly; legal, technical, financial and environmental provisions. However, the basic concerns among involved parties are the economic and financial issues (Rights \& Obligations). These issues arise from the economic feasibility study which is prepared separately by each party. In this area, contracts focus on special requirements such as the amount of capital and pricing mechanisms, work programs, and the value of outputs and risks; therefore, the feasibility study is different comparing with studies in other industries. Furthermore, as the petroleum contracts focus, among other things, on accurate rights and obligations, so this work is not smooth and needs a long time and different experiences. Feasibility studies are often complex and expensive; therefore, centering on the net ultimate values of Host
Government and Oil Company is the basic goal of a feasibility study.

\section{2: Techniques:}

Conducting feasibility studies in this industry depend on a good understanding and awareness of the conceptual framework of a petroleum contract, as well as economic and financial issues related to techniques and mechanisms for computing costs and revenues and splitting the shares among involved parties (Host Government and Oil Company) such as taxes, royalties, bonuses, Profit Oil and Cost Oil, Rfactor, price cap, etc., see Table (4).

\section{3: Types of Contracts:}

In general, petroleum contracts are divided into three main categories; Concession Contracts, Production Sharing Contracts, and Service Contracts, see Figure (2). 
Table (4)

Selected Financial \& Economic Items of Petroleum Contracts

\begin{tabular}{|c|c|c|}
\hline $\begin{array}{c}\text { Some Fiscal Terms } \\
\text { in Petroleum } \\
\text { Contract }\end{array}$ & Techniques & $\begin{array}{c}\text { Some Terms Subject to } \\
\text { Sliding Scale }\end{array}$ \\
\hline $\begin{array}{l}\text { Bonuses } \\
\text { Royalty } \\
\text { Cost Oil } \\
\text { Cost Recovery } \\
\text { Profit Oil } \\
\text { Taxes } \\
\text { Gov. Participation } \\
\text { Commerciality } \\
\text { Domestic Obligations } \\
\text { Ring Fencing } \\
\text { Gov. Take } \\
\text { Co. Take }\end{array}$ & $\begin{array}{l}\text { Sliding Scale } \\
\text { R - Factor } \\
\text { Rate of Return } \\
\text { Price Cap } \\
\text { Net Back Value }\end{array}$ & $\begin{array}{l}\text { Profit Oil Split } \\
\text { Royalty } \\
\text { Bonuses } \\
\text { Cost Recovery Limits } \\
\text { Tax Rates } \\
\text { Uplifts }\end{array}$ \\
\hline
\end{tabular}

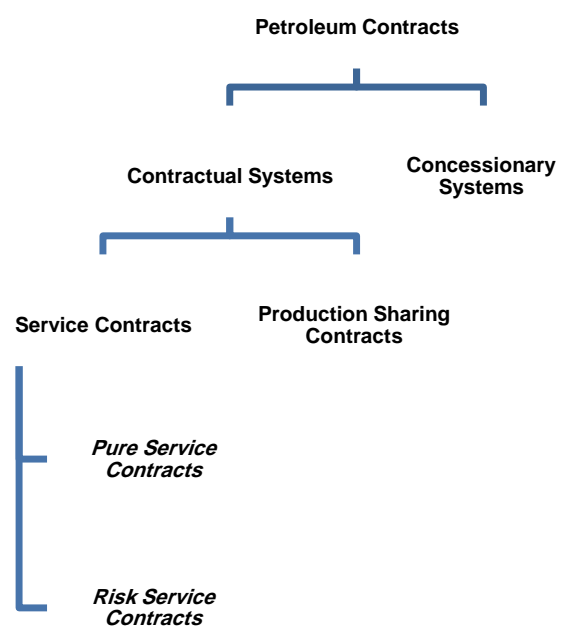

Fig (2)

Main Types of Petroleum Contracts 
Historically, concessions are the oldest type; tax and royalty are main elements of the relationship between the Host Government and the Oil Company. Production sharing contracts began in the sixties and they involve more complex mechanisms in computing costs and profits.

There are a number of service contracts types and there is no one standard model, but this type of contract has a basic point called a service fee which shall be covered by petroleum costs and a certain return for the Oil Company. In general, many considerations may determine the trends of a relationship between involved parties, mainly; ownership, payments, profit split, working program, and risk level.

\section{$\underline{\underline{P a r t} \text { Six }}$}

\section{Case Studies}

\section{General Comments:}

It goes without saying that diversity of petroleum projects makes their economic and financial features different. A general framework of costs and revenues and profitability indicators in any given project's feasibility study hides many complex details, including all items throughout the earlier steps until the final study. Typically, the main focus is not only on the final result itself, but significant attention is also given to the original sources of costs and revenues and the unusual circumstances associated with the performance of the project.

It is useful in this area, and as an integral chain, to take some examples (just for illustrating the main parts of cash flow) of selected petroleum projects, particularly cases include general inputs and the main results of cash flows derived from long and complex stages related to market, technical, and financial studies reaching the following briefs.

\section{2 .Upstream Projects:}

In general, feasibility studies of upstream projects are more complex and often take a long time and require high experience. The main emphasis is on the quantities and qualities of oil and gas reserves, 
extracting abilities, potential indicators. Any expected risks production rates, time scheduling, associated over the life of project are investments requirements, and considered with a high degree of operating costs. More attention is accuracy. Table (5) shows an also given to the future values of oil and gas reserves and profitability example of a production sharing contract (from Oil Company's viewpoint).

Table (5)

Production Sharing Contract: Simple Example

\begin{tabular}{|c|c|c|c|c|c|c|c|}
\hline & 2011 & 2012 & 2013 & 2014 & 2015 & 2016 & Total \\
\hline \multicolumn{8}{|l|}{ INPUT (\$MM) } \\
\hline Oil Production (MMBbl) & & & 10 & 10 & 10 & 10 & 40 \\
\hline Oil Price (\$/Bbl) & & & 30 & 30 & 30 & 30 & \\
\hline Revenue & & & 300 & 300 & 300 & 300 & 1200 \\
\hline Operating Cost - & & & 10 & 10 & 10 & 10 & 40 \\
\hline Exploration Capital - & 50 & & & & & & 50 \\
\hline Development Capital - & & 250 & & & & & 250 \\
\hline \multicolumn{8}{|l|}{ Calculations (\$MM) } \\
\hline Royalty & & & 30 & 30 & 30 & 30 & 120 \\
\hline Eligible Cost Recovery & & & 310 & 10 & 10 & 10 & \\
\hline CR Carry foreword Used & & & & 70 & & & \\
\hline Adjusted Cost Recovery & & & 310 & 80 & 10 & 10 & \\
\hline Cost Recovery Ceiling & & & 240 & 240 & 240 & 240 & \\
\hline CR Carry Foreword & & & 70 & & & & \\
\hline Cost Recovery Taken + & & & 240 & 80 & 10 & 10 & 340 \\
\hline Profit Oil to be Shared & & & 30 & 190 & 260 & 260 & 740 \\
\hline Profit Oil + & & & 18 & 114 & 156 & 156 & 444 \\
\hline Net Cash Flow & -50 & -250 & 248 & 184 & 156 & 156 & 444 \\
\hline
\end{tabular}

Source: IHS, ENERGY.

Note: Under assumptions of $60 \%$ Profit Share, $80 \%$ Cost Recovery Ceiling, and $10 \%$ Royalty. 


\section{Gas Projects:}

The logic of the work in gas processing plants is almost the same as the work in refining projects, but the main focus is given to the feed gas of the plant, products of processed gas, buyers' obligations, and some other related issues.

\section{Pipeline Projects:}

The main elements for the pipeline projects that are considered within the economic feasibility study are; the investment needs to establish the pipeline, operating costs, and the sources of revenue such as tariffs or any form of returns related to the running of oil, gas and products pipelines.

\section{Refining Projects:}

Concerning refining projects is different in terms of operations, area and technology, their plants and activities that related to the refining of crude oil are on the ground. The main focus in this context is on the investments, projections of crude oil and product prices, operating costs and product markets and technological developments. Parts of Table (6) give some details about some items in an economic feasibility study of a particular refinery project (in US 2002 
Table (6)

Selected Calculations from Refinery Project

\section{A: Capital Costs}

\begin{tabular}{|c|c|}
\hline Engineering \$ & $\mathbf{5 , 2 6 6 , 8 0 0}$ \\
Site Facilities & $\mathbf{2 1 , 8 2 4 , 0 0 0}$ \\
Process Units: & \\
Crude Unit & $\mathbf{6 , 4 8 2 , 0 0 0}$ \\
Naphtha HDS & $\mathbf{5 , 1 0 0 , 0 0 0}$ \\
Reformer & $\mathbf{1 4 , 7 0 0 , 0 0 0}$ \\
Unicracker & $\mathbf{1 3 , 8 0 0 , 0 0 0}$ \\
Sour Gas/Sulfur Treating & $\mathbf{1 , 7 0 0 , 0 0 0}$ \\
Other Infrastructure & $\mathbf{1 , 6 0 3 , 0 0 0}$ \\
Contingency & $\mathbf{1 0 , 5 7 1 , 3 7 0}$ \\
Total Fixed Capital Cost & $\mathbf{8 1 , 0 4 7 , 1 7 0}$ \\
Working Capital & $\mathbf{5 , 6 6 2 , 3 3 3}$ \\
\hline Total Project Capital \$ & $\mathbf{8 6 , 7 0 9 , 5 0 3}$ \\
\hline
\end{tabular}

\section{B: Crude Oil Price}

\begin{tabular}{|c|c|}
\hline Base Crude \$/bbl & 26.33 \\
Competitive \$/bbl & - \\
Crude Cost \$/bbl 26.33 - 32.81 & 26.33 \\
\hline Cost per Day \$/d & 158 \\
\hline
\end{tabular}

\section{C: Daily Operating Costs}

\begin{tabular}{|l|c|}
\hline Natural Gas \$ & 12,254 \\
Electricity & 2,179 \\
Water & 170 \\
Chemicals & 7,144 \\
Royalties & 375 \\
Labor & 7,870 \\
Maintenance Supplies & $\mathbf{8 0 0}$ \\
\hline \multicolumn{2}{|c|}{ Total \$ } \\
\end{tabular}

D: Value of Products \$/day

\begin{tabular}{|c|c|c|c|c|}
\hline & Bbl/dy & Gal/dy & \$/Gal & \$/dy \\
\hline Gasoline & 3600 & 151200 & 1.03 & 156,184 \\
Kerosene & 470 & 19740 & $\mathbf{1 . 0 8}$ & $\mathbf{0 . 9 5}, 384$ \\
Diesel & 1900 & 49800 & 0.71 & 75,633 \\
Oil & 12 & 493.5 & & 253,552 \\
\hline
\end{tabular}


E: Main Results

\begin{tabular}{|l|l|}
\hline Capital Investment & $\mathbf{8 6 , 7 0 9 , 5 0 3}$ \\
Value of Products & $\mathbf{8 7 , 4 7 5 , 3 4 3}$ \\
Cost of Crude Oil Feed & $(54,493,440)$ \\
Operating Expense & $(10,623,391)$ \\
Depreciation & $(5,065,448)$ \\
\hline Net Profit & \multicolumn{1}{|c|}{$17,293,064$} \\
Return on Investment & $20 \%$ \\
\hline
\end{tabular}

Source: John D., \& P.E.

\section{Conclusions:}

1-Developments in the world economy and business life have made petroleum projects more complex and very sensitive to changing conditions, especially to the markets, prices, and advanced technologies.

2-Many developments should be considered for any modern economic feasibility study, and to make that possible, many issues are required; new mathematical and statistical and financial skills, modern software programs, experience in preparing detailed feasibility studies, experience in legal issues, as well as capabilities in the forecasting of future technical and non-technical developments in the petroleum industry.

3-Gathering theoretical considerations, practical experience, and technological developments is the cornerstone in conducting a complete economic feasibility study of petroleum projects.

4-Increasing the details of feasibility topics such as (financing, contracting, negotiating, procurements, supply multiline, environmental issues....) made the process of feasibility study more difficult and complex, so it needs more time and more fund, as well as the international consultants/offices advices to achieve a completed study especially for the large and extensive petroleum projects. 


\section{References:}

1. BERA.."The Oil \& Gas Industry".(2010).

www.loc.gov/rr/business/BERA/issue5/issue5_main.html.

2. Bernard Taverne "Petroleum Industry and Governments", International Energy and Resources Law and Policy Series, London, 2000.

3. Daniel Johnston" International Petroleum Fiscal Systems and Production Sharing Contracts", PennWell Books, USA, 1994.

4. David S.Clifton and David E.Fyffe "Project Feasibility Analysis", A WileyInterscience Publication, New York, 1977.

5. Guy Allinson "Economics of Petroleum Exploration and Production: Course Notes", 1998.

6. HIS ENERGY" Oil and Gas Economic and Fiscal Analysis", Training Course for Ministry of Oil, Iraq, 2005.

7. John D. Jones, P.E. "Feasibility Study for a Petroleum Refinery for the Jicarilla Apache Tribe", JOHN D. JONES ENGINEERING, INC., USA, 2004.

8. Krishan A. Malik "Petroleum Project Evaluation \& Investment decisionMaking", Institute for Petroleum Development Inc, USA, the year is not available.

9. Mohamed A. Ashosh" Managerial Studies in Economics of Project", Arabic Copy, Center of Cairo University for Open Education, Egypt, 1993.

10. MTD International "Projects Economics \& Decision Making", Training Course Manual for OPEC Staff, UK, 2004.

11. Richard D.Seba "Economics of Worldwide Petroleum Production", OGCL and Petroskills Publications, USA, 2003.

12. Sadik Hamed and Hanafy Zaki" Accounting Study for Project Feasibility", Arabic Copy, Center of Cairo University for Open Education, Egypt, 1998.

13. W.Behrens and P.Hawranek "Manual for Preparation of Industrial Feasibility Studies" UNIDO, Vienna, 1991. 